\title{
Influences of Length of Photoperiod on the Adrenocortical Activity of the Male Blossomheaded Parakeet Psittacula cyanocephala
}

\author{
Saumen Kumar Maitra*
}

\begin{abstract}
Adult male Blossomheaded Parakeets were exposed to very long ( $22 \mathrm{~h})$ and very short $(2 \mathrm{~h})$ daily photoperiods for 45 days during different phases of the annual testicular cycle. Adrenocortical activity of the experimental photoperiodic birds were compared with that of parallely held natural photoperiodic birds with the use of different histophysiological parameters. These parameters are believed to be faithful indices of secretory functions in the steroidogenic part of avian adrenal gland. The study revealed that very short $(2 \mathrm{~h} /$ day $)$ day-length does not influence the activity of adrenocortical tissue in any phase of the annual cycle. Adrenocortical tissue of very long photoperiodic (22 L : $2 \mathrm{D}$ ) birds (i) remains unaffected during breeding phase, (ii) shows the features of inactiveness in the subcapsular zone (SCZ) during late preparatory, early progressive and prebreeding phases of treatment, and (iii) becomes atrophied in both the SCZ and IZ (inner zone) when the birds were exposed during early preparatory and late progressive phases of the annual gonadal cycle.

The results of this study are discussed in the light of previous studies into photoperiodic effects on adrenocortical activity in parakeets.
\end{abstract}

\section{Introduction}

The adrenocortical tissue is known to undergo seasonal changes in a number of birds (cf. Silverin 1979, Deviche 1983, Peczely 1985, Maitra 1987a). Though precise mechanism involved in the periodic activation of the steroidogenic part of adrenal is not clearly known, many workers support the conjecture that this endocrine moiety is probably involved in the photoperiodic regulation of gonadal functions in birds (Meier et al. 1971, Meier \& Dusseau 1973, Wilson \& Follett 1975, Assenmacher \& Jallageas 1980, Deviche 1983, Peczely 1985). But, to the knowledge of the author, no systematic study has yet been made to examine the behaviour of adrenal cortex under altered photoperiodic regimens during different phases of the annual cycle in a single species of bird. Accordingly, an attempt has been made to study the responses, if any, of adrenocortical tissue to very long and very short daily photoperiods, which are known to exert variable influences on the testicular activity during different phases of the annual cycle of male Blossomheaded Parakeets (Maitra 1987b).

\section{Materials and Methods}

The experimental material, mode of collection and pre-conditioning of the materials, and the experimental schedules adopted in the present investigation were the same as reported in the communication (Maitra 1987b) dealt with the influences of length of

Received 18 July 1988; accepted 5 November 1988

* Department of Zoology, University of Burdwan, Golapbag, Burdwan 713 104, India 


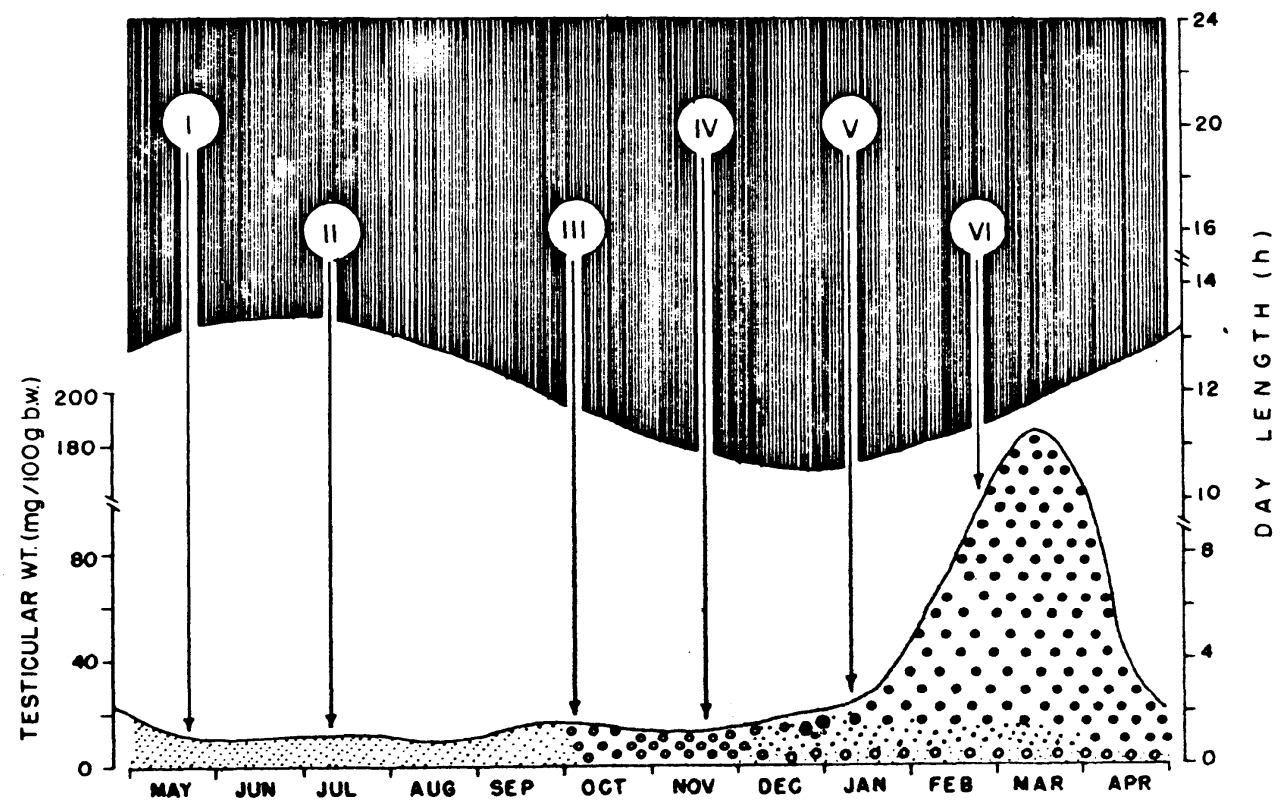

Fig. 1. Diagrammatic presentation of the experimental schedules adopted for the studies of adrenocortical responses to altered photoperiods during different phases of the annual testicular cycle in Blossomheaded Parakeet in relation to the annual changes in day length. Arrows with Roman digits refer to reproductive phases in the cycle when birds were collected and used for photoperiodic experiments. Each time, birds were equally divided into three different groups and parallely held under three different photoperiodic schedules: (a) very long daily photoperiods (22 L : $2 \mathrm{D})$, (b) very short daily photoperiods (2 L : $22 \mathrm{D})$, and (c) natural photoperiods (varied in relation to the months of experiment as presented in the diagram). The duration of treatment was in each case 45 days. Different symbols have been used within the curve of testicular weight to signify the germinal status of testes in parakeets.

Key to symbols: Fine dots - spermatogonia; open circles--primary spermatocytes; coarse dots-secondary spermatocytes and spermatids; solid circles-sperms.

Key to Roman digits: I-Early preparatory; II-Late preparatory; III--Early progressive; IV-Late Progressive; V-CPre-breeding; VI-Breeding. Reproductive phase was confirmed from the study of randomly selected 3 to 4 birds prior to the beginning of each experiment.

photoperiods on the testicular activities of Blossomheaded Parakeet. A brief account of the same is given for the present purpose.

The study has been made on adult male Blossomheaded Parakeets which acquire a definitive plumage after the first winter that remains unaltered throughout the year (Ali \& Ripley 1969). Adult male parakeets were collected from natural population in the adjacent areas of Calcutta $\left(22^{\circ} 36^{\prime} \mathrm{N}, 88^{\circ} 24^{\prime} \mathrm{E}\right)$ and maintained under laboratory conditions (photoperiod and temperature: unaltered; population: 3-4 birds in each cage measuring $90 \times 60 \times 30 \mathrm{~cm}$; food, paddy grain, and water ad libitum) at least for a week before being used for experimental purposes. 
Table 1. Adrenocortical responses to different photoperiods for 45 days durations during early and late preparatory phases of the annual gonadal cycle of Blossomheaded Parakeet (values are mean ${ }^{\text {S.E.) }}$

\begin{tabular}{|c|c|c|c|c|c|c|c|c|c|}
\hline \multirow{2}{*}{$\begin{array}{c}\text { Reproduc- } \\
\text { tive } \\
\text { phase }\end{array}$} & \multirow{2}{*}{$\begin{array}{l}\text { Photo- } \\
\text { periodic } \\
\text { group }\end{array}$} & \multirow{2}{*}{$\begin{array}{c}\text { Relative } \\
\text { adrenal } \\
\text { weight } \\
\text { (mg/100 g } \\
\text { body wt.) }\end{array}$} & \multicolumn{2}{|c|}{$\begin{array}{l}\text { Cortical cord } \\
\text { width } \\
(\mu \mathrm{m})\end{array}$} & \multicolumn{2}{|c|}{$\begin{array}{l}\text { Nuclear } \\
\text { diameter } \\
(\mu \mathrm{m})\end{array}$} & \multirow{2}{*}{$\begin{array}{l}\text { Adrenal } \\
\text { choles- } \\
\text { terol } \\
(\mu \mathrm{g} / \mathrm{mg})\end{array}$} & \multicolumn{2}{|c|}{$\begin{array}{c}\text { Intensity of } \\
\text { Sudanophilic } \\
\text { lipids }\end{array}$} \\
\hline & & & $\mathrm{SCZ}$ & IZ & $\mathrm{SCZ}$ & IZ & & $\mathrm{SCZ}$ & IZ \\
\hline \multirow[t]{3}{*}{$\begin{array}{l}\text { Preparatory } \\
\text { (early) }\end{array}$} & NP (21) & $\begin{array}{r}19.58 \\
\pm 1.04\end{array}$ & $\begin{array}{r}37.05 \\
\pm 0.61\end{array}$ & $\begin{array}{r}37.22 \\
\pm 0.40\end{array}$ & $\begin{array}{r}5.01 \\
\pm 0.09\end{array}$ & $\begin{array}{r}5.63 \\
\pm 0.11\end{array}$ & $\begin{array}{r}33.27 \\
\pm 0.37\end{array}$ & $2+/ 3+$ & $3+$ \\
\hline & LP (10) & $\begin{array}{c}20.16 \\
\pm 1.34\end{array}$ & $\begin{array}{c}32.85 \\
\pm 0.28^{b}\end{array}$ & $\begin{array}{c}33.23 \\
\pm 0.22^{b}\end{array}$ & $\begin{aligned} & 3.98 \\
+ & 0.03^{b}\end{aligned}$ & $\begin{array}{c}5.13 \\
+0.11^{\mathrm{a}}\end{array}$ & $\begin{array}{c}56.22 \\
\pm 4.87^{b}\end{array}$ & $4+$ & $4+$ \\
\hline & SP (13) & $\begin{array}{c}21.64 \\
\pm 0.90^{*}\end{array}$ & $\begin{array}{c}37.24 \\
\pm 0.41\end{array}$ & $\begin{array}{c}35.85 \\
\pm 0.96 *\end{array}$ & $\begin{array}{c}5.03 \\
\pm 0.09 *\end{array}$ & $\begin{array}{c}5.75 \\
+0.06 *\end{array}$ & $\begin{array}{c}35.44 \\
\pm 1.86 *\end{array}$ & $3+$ & $3+$ \\
\hline \multirow[t]{3}{*}{$\begin{array}{l}\text { Preparatory } \\
\text { (late) }\end{array}$} & NP (6) & $\begin{array}{r}17.64 \\
\pm 2.04\end{array}$ & $\begin{array}{r}35.75 \\
\pm 0.82\end{array}$ & $\begin{array}{r}35.08 \\
\pm 0.68\end{array}$ & $\begin{array}{r}4.97 \\
+0.08\end{array}$ & $\begin{array}{r}4.92 \\
\pm 0.09\end{array}$ & $\begin{array}{r}38.41 \\
\pm 2.20\end{array}$ & $2+/ 3+$ & $3+$ \\
\hline & LP (6) & $\begin{array}{c}19.06 \\
\pm 5.24 *\end{array}$ & $\begin{array}{c}30.02 \\
+0.26^{b}\end{array}$ & $\begin{array}{c}34.56 \\
\pm 0.52 *\end{array}$ & $\begin{array}{r}3.62 \\
+0.12^{\mathrm{b}}\end{array}$ & $\begin{array}{c}4.76 \\
+0.11 *\end{array}$ & $\begin{array}{r}51.26 \\
\pm 1.21^{\mathrm{b}}\end{array}$ & $4+$ & $3+$ \\
\hline & SP (6) & $\begin{array}{c}18.44 \\
+4.16 *\end{array}$ & $\begin{array}{c}34.68 \\
\pm 0.51\end{array}$ & $\begin{array}{c}34.71 \\
\pm 0.61\end{array}$ & $\begin{array}{c}4.88 \\
\pm 0.11\end{array}$ & $\begin{array}{r}4.82 \\
+0.08 *\end{array}$ & $\begin{array}{c}39.82 \\
\pm 2.42\end{array}$ & $3+$ & $3+$ \\
\hline
\end{tabular}

Figure in the parenthesis denotes the number of birds used.

NP: Natural photoperiod (varied from $10 \mathrm{~h}$ to $13 \mathrm{~h}$ zone); LP: Long photoperiod (22 L : $2 \mathrm{D}$ ); SP: Short photoperiod (2 L : $22 \mathrm{D})$

*: Statistically not significant (data compared to respective control i. e. NP); ${ }^{\mathrm{a}}$ : $\mathbf{P}<0.005 ;{ }^{\mathrm{b}}: \mathbf{P}<0.001$

Identical photoperiodic experiments have been conducted during different phases (Fig. 1) of the annual testicular cycle of the Blossomheaded Parakeet (Maitra 1986). In each phase, freshly collected birds were divided into three different groups, which subsequently experienced different schedules of photoperiodic exposures, i.e., (a) 22 hours of light with 2 hours of darkness (22 L : 2 D), (b) 2 hours of light with 22 hours of darkness (2 L : $22 \mathrm{D}$ ), and (c) natural photoperiods (varied in between $10 \mathrm{~h}$ and $13 \mathrm{~h} 30$ $m$ depending upon the phase of treatment). All the birds were maintained under identical conditions, other than the photoperiods, for 45 days.

At the termination of each experiment, birds were killed in between $14.00 \mathrm{~h}$ and 16.00 $\mathrm{h}$ by cervical dislocation. After taking final body weight, quick dissection was performed to remove both the adrenals, which were subsequently made free from surrounding tissues and weighed with the use of an analytical balance sensitive to $0.01 \mathrm{mg}$. Left adrenal was fixed in Wood's buffered fixative (Wood 1963), dehydrated in alcohol and routine microtomy was followed to obtain $4 \mu \mathrm{m}$ thick paraffin sections. The sections were stained with Masson's trichrome stains (Maitra 1981). Diameters of at least 30 Cortical Cords and 100 round nuclei from each of the subcapsular and inner zones were measured from the stained sections of adrenal with the help of a calibrated scale of an eye piece ocular for obtaining mean values for each individual (Silverin 1979, Maitra 1981, 1985, 1987a, Maitra \& Chakraborty 1983). A portion of the right adrenal was processed for quantitative estimation of total cholesterol (Zarrow et al. 1964) and another part was fixed in formal-calcium fixative and frozen microtomy was followed by staining of $10 \mu \mathrm{m}$ thick sections with Sudan III \& IV (Maitra 1985, 1987a). The intensity of Sudan-reactive lipids 
Table 2. Adrenocortical responses to different photoperiods for 45 days durations during early and late progressive phases of the annual gonadal cycle of Blossomheaded Parakeet (values are mean \pm S.E.)

\begin{tabular}{|c|c|c|c|c|c|c|c|c|c|}
\hline \multirow{2}{*}{$\begin{array}{l}\text { Reproduc- } \\
\text { tive } \\
\text { phase }\end{array}$} & \multirow{2}{*}{$\begin{array}{l}\text { Photo- } \\
\text { periodic } \\
\text { group }\end{array}$} & \multirow{2}{*}{$\begin{array}{c}\text { Relative } \\
\text { adrenal } \\
\text { weight } \\
\text { (mg/100 g } \\
\text { b.w.) }\end{array}$} & \multicolumn{2}{|c|}{$\begin{array}{l}\text { Cortical Cord } \\
\text { width } \\
(\mu \mathrm{m})\end{array}$} & \multicolumn{2}{|c|}{$\begin{array}{c}\text { Nuclear } \\
\text { diameter } \\
(\mu \mathrm{m})\end{array}$} & \multirow{2}{*}{$\begin{array}{l}\text { Adrenal } \\
\text { choles- } \\
\text { terol } \\
(\mu \mathrm{g} / \mathrm{mg})\end{array}$} & \multicolumn{2}{|c|}{$\begin{array}{c}\text { Intensity of } \\
\text { Sudanphilic } \\
\text { lipids }\end{array}$} \\
\hline & & & $\mathrm{SCZ}$ & IZ & $\mathrm{SCZ}$ & IZ & & $\mathrm{SCZ}$ & IZ \\
\hline \multirow[t]{3}{*}{$\begin{array}{l}\text { Progressive } \\
\text { (early) }\end{array}$} & NP (6) & $\begin{array}{r}18.16 \\
\pm 4.72\end{array}$ & $\begin{array}{r}30.58 \\
\pm 1.15\end{array}$ & $\begin{array}{r}30.22 \\
\pm 0.73\end{array}$ & $\begin{array}{r}5.35 \\
\pm 0.16\end{array}$ & $\begin{array}{r}5.39 \\
+0.13\end{array}$ & $\begin{array}{c}32.6 \\
\pm 1.68\end{array}$ & $3+/ 4+$ & $4+$ \\
\hline & LP (6) & $\begin{array}{c}14.84 \\
\pm 3.64 *\end{array}$ & $\begin{array}{c}24.65 \\
\pm 0.96^{c}\end{array}$ & $\begin{array}{c}30.84 \\
\pm 0.65 *\end{array}$ & $\begin{aligned} & 4.83 \\
\pm & 0.14^{\mathrm{a}}\end{aligned}$ & $\begin{array}{c}5.51 \\
+0.08 *\end{array}$ & $\begin{array}{c}44.41 \\
\pm 1.02^{\mathrm{c}}\end{array}$ & $5+$ & $3+/ 4+$ \\
\hline & SP (6) & $\begin{array}{c}15.28 \\
\pm 2.54 *\end{array}$ & $\begin{array}{c}31.09 \\
\pm 0.62 *\end{array}$ & $\begin{array}{c}32.90 \\
\pm 0.76 *\end{array}$ & $\begin{array}{c}5.14 \\
\pm 0.25 *\end{array}$ & $\begin{array}{c}5.47 \\
\pm 0.21 *\end{array}$ & $\begin{array}{c}38.82 \\
\pm 2.63\end{array}$ & $4+$ & $3+/ 4+$ \\
\hline \multirow[t]{3}{*}{$\begin{array}{l}\text { Progressive } \\
\quad \text { (late) }\end{array}$} & NP (7) & $\begin{array}{r}15.86 \\
\pm 3.32\end{array}$ & $\begin{array}{r}38.66 \\
\pm 0.89\end{array}$ & $\begin{array}{r}38.62 \\
\pm 1.90\end{array}$ & $\begin{array}{r}5.74 \\
\pm 0.13\end{array}$ & $\begin{array}{r}5.82 \\
\pm 0.12\end{array}$ & $\begin{array}{r}18.88 \\
\pm 2.26\end{array}$ & $2+$ & $3+$ \\
\hline & LP (7) & $\begin{array}{c}14.66 \\
\pm 2.62\end{array}$ & $\begin{array}{c}29.22 \\
\pm 0.78^{d}\end{array}$ & $\begin{array}{c}32.78 \\
\pm 1.13^{\mathrm{a}}\end{array}$ & $\begin{aligned} & 4.47 \\
\pm & 0.10^{\mathrm{d}}\end{aligned}$ & $\begin{aligned} & 5.38 \\
\pm & 0.06^{\mathrm{b}}\end{aligned}$ & $\begin{array}{c}28.16 \\
\pm 0.47^{c}\end{array}$ & $4+$ & $4+$ \\
\hline & SP (7) & $\begin{array}{c}13.82 \\
\pm 2.90 *\end{array}$ & $\begin{array}{c}36.62 \\
\pm 1.67 *\end{array}$ & $\begin{array}{c}37.06 \\
\pm 1.16 *\end{array}$ & $\begin{array}{c}5.62 \\
+0.07 *\end{array}$ & $\begin{array}{c}5.93 \\
+0.08 *\end{array}$ & $\begin{array}{c}24.22 \\
\pm 2.75\end{array}$ & $2+$ & $3+$ \\
\hline
\end{tabular}

${ }^{\mathrm{a}}$; $\mathrm{P}<0.025$; $^{\mathrm{b}} ; \mathrm{P}<0.01$; $^{\mathrm{c}} ; \mathrm{P}<0.005$; ${ }^{\mathrm{d}} ; \mathrm{P}<0.001$; NP: Natural photoperiod (varied from $12 \mathrm{~h}$ to $10 \mathrm{~h} 30 \mathrm{~m}$ ). Other legends are same as in Table 2.

in the adrenal was visually determined on an arbitrary scale of 0 to 5 . Statistical analyses of gravimetric, histometric, karyometric and quantitative biochemical data were done following Student's 't' test (Fisher 1963).

\section{Results}

Gravimetry: The mean weight value of body and paired adrenal glands in different groups of experimental birds, irrespective of the experience of photoperiodic schedules and reproductive phase of treatment, did not show any statistical change from that recorded with th respective natural photoperiodic birds (see Table 1-3).

Histology, histometry and karyometry: General histology of adrenal cortex in Blossomheaded parakeet has been described earlier (Maitra 1981, 1985, Maitra and Chakraborty 1983). It is worthmentioning here that histomorphologically this endocrine tissue (see Figs. 2 \& 4) can be differentiated into outer subcapsular zone (SCZ) and inner zone (IZ), both of which undergo precise seasonal changes parallel with the testicular cycle of Blossomheaded Parakeet (Maitra 1987b).

In the present investigation, marked atrophy of the adrenocortical cells was noted in the gland of very long photoperiodic (22 L : $2 \mathrm{D}$ ) parakeets during different phases, other than the breeding phase, of the annual gonadal cycle. But the distribution of atrophied cells was not uniform in the adrenal cortex of different groups of long photoperiod responsive birds. During pre-breeding, late preparatory and early progressive phases marked atrophy of the adrenocortical cells was restricted to the SCZ of the gland (Fig. 3), while during early preparatory and late progressive phases of the annual testicular cycle 
Table 3. Adrenocortical responses to different photoperiods for $\mathbf{4 5}$ days during pre-breeding and breeding phases of the annual gonadal cycle of Blossomheaded Parakeet (Values are mean + S.E.)

\begin{tabular}{|c|c|c|c|c|c|c|c|c|c|}
\hline \multirow{2}{*}{$\begin{array}{l}\text { Reproduc- } \\
\text { tive } \\
\text { phase }\end{array}$} & \multirow{2}{*}{$\begin{array}{l}\text { Photo- } \\
\text { periodic } \\
\text { group }\end{array}$} & \multirow{2}{*}{$\begin{array}{c}\text { Relative } \\
\text { adrenal } \\
\text { weight } \\
\text { (mg/100 g } \\
\text { b.w.) }\end{array}$} & \multicolumn{2}{|c|}{$\begin{array}{l}\text { Cortical cord } \\
\text { width } \\
(\mu \mathrm{m})\end{array}$} & \multicolumn{2}{|c|}{$\begin{array}{c}\text { Nuclear } \\
\text { diameter } \\
(\mu \mathrm{m})\end{array}$} & \multirow{2}{*}{$\begin{array}{l}\text { Adrenal } \\
\text { choles- } \\
\text { terol } \\
(\mu \mathrm{g} / \mathrm{mg})\end{array}$} & \multicolumn{2}{|c|}{$\begin{array}{l}\text { Intensity of } \\
\text { Sudanophilic } \\
\text { lipids }\end{array}$} \\
\hline & & & $\mathrm{SCZ}$ & IZ & $\mathrm{SCZ}$ & IZ & & $\mathrm{SCZ}$ & $\mathrm{IZ}$ \\
\hline \multirow[t]{3}{*}{ Pre-breeding } & NP (6) & $\begin{array}{r}21.26 \\
\pm 2.26\end{array}$ & $\begin{array}{r}34.08 \\
+\quad 0.55\end{array}$ & $\begin{array}{r}31.76 \\
+0.68\end{array}$ & $\begin{array}{r}4.86 \\
+0.10\end{array}$ & $\begin{array}{r}5.23 \\
+0.04\end{array}$ & $\begin{array}{r}28.47 \\
+2.16\end{array}$ & + & $2+$ \\
\hline & LP (7) & $\begin{array}{c}18.08 \\
\pm 0.50 *\end{array}$ & $\begin{array}{c}29.79 \\
\pm 0.61^{b}\end{array}$ & $\begin{array}{c}30.49 \\
\pm 0.50\end{array}$ & 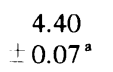 & $\begin{array}{l}5.17 \\
\pm 0.09 *\end{array}$ & $\begin{array}{c}45.02 \\
+3.88^{\mathrm{a}}\end{array}$ & $3+$ & 2 \\
\hline & SP (6) & $\begin{array}{c}16.64 \\
\pm 1.54\end{array}$ & $\begin{array}{c}32.61 \\
\pm 1.11\end{array}$ & $\begin{array}{r}30.87 \\
+0.80\end{array}$ & $\begin{array}{c}4.74 \\
+0.11\end{array}$ & $\begin{array}{c}5.43 \\
\pm 0.12 *\end{array}$ & $\begin{array}{c}34.53 \\
+2.90 *\end{array}$ & + & $2+$ \\
\hline \multirow[t]{3}{*}{ Breeding } & NP (6) & $\begin{array}{r}17.40 \\
\pm 1.82\end{array}$ & $\begin{array}{r}38.37 \\
+0.82\end{array}$ & $\begin{array}{r}36.74 \\
+0.94\end{array}$ & $\begin{array}{r}4.64 \\
+0.09\end{array}$ & $\begin{array}{r}5.01 \\
+0.10\end{array}$ & $\begin{array}{r}43.50 \\
+4.37\end{array}$ & $3+$ & $3+$ \\
\hline & LP (7) & $\begin{array}{c}15.56 \\
\pm 1.48 *\end{array}$ & $\begin{array}{c}36.42 \\
\pm 1.40 *\end{array}$ & $\begin{array}{c}36.38 \\
\pm 1.65 *\end{array}$ & $\begin{array}{c}4.50 \\
\pm 0.09 *\end{array}$ & $\begin{array}{c}5.12 \\
\pm 0.08 *\end{array}$ & $\begin{array}{c}56.26 \\
\pm 8.52 *\end{array}$ & $3+/ 4+$ & $3+/ 4+$ \\
\hline & SP (6) & $\begin{array}{c}15.44 \\
\pm 2.40 *\end{array}$ & $\begin{array}{r}36.13 \\
\pm 0.85\end{array}$ & $\begin{array}{l}35.86 \\
\pm 0.78 *\end{array}$ & $\begin{array}{c}4.58 \\
\pm 0.12 *\end{array}$ & $\begin{array}{c}5.03 \\
\pm 0.15^{*}\end{array}$ & $\begin{array}{c}52.55 \\
\pm 7.03 *\end{array}$ & $3+/ 4+$ & $3+/ 4+$ \\
\hline
\end{tabular}

${ }^{\mathrm{a}}: \mathrm{P}<0.005 ;{ }^{\mathrm{b}}: \mathrm{P}<0.001 ; \mathrm{NP}=$ Natural photoperiod (varied from $10 \mathrm{~h} 30 \mathrm{~m}$ to $12 \mathrm{~h} 30 \mathrm{~m}$ ). Other legends are same as in Table 2.

abundance of pycnotic nuclei in the degenarated cells was seen in both the SCZ and IZ of adrenal cortex (Fig. 5) of long photoperiodic birds. Treatment during breeding phase did not cause any change in the histomorphology of the gland.

Histometric and karyometric studies also revealed significant decrease in the cortical cord width and diameter of nuclei in the cortical cells in either SCZ in the gland of long photoperiodic birds considered for treatment during pre-breeding, late preparatory and early progressive phases or, in both the SCZ and the IZ in adrenals of similarly treated birds during early preparatory and late progressive phases of the annual cycle (see Table 1-3). The histometric and karyometric values recorded with the study of adrenal glands

Figs. 2-5. Paraffin embedded Masson's trichrome stained sections of adrenal glands $(\times 480)$ to show differential responsiveness of cortical tissue to identical duration ( 45 days) of long photoperiodic regimen (22 L : $2 \mathrm{D}$ ) during different phases of the annual reproductive cycle.

Fig. 2. Adrenal cortex showing healthy cells in both the subcapsular (SCZ) and inner zones (IZ) of the gland in the bird captured during pre-breeding phase (January) and held under natural day-lengths until being killed on 25th February.

Fig. 3. Marked atrophy of the adrenocortical cells restricted to the SCZ can be noticed with the tissue of the bird exposed to long photoperiods during same reproductive phase as stated with Fig. 2.

Fig. 4. Adrenocortical tissue of the parakeet collected during late progressive phase (November) and kept on seasonal day-lengths until 3rd January.

Fig. 5. Note abundance of pycnotic nuclei in the atrophied cells of both the SCZ and IZ of the adrenal cortex of the parallely held long-photoperiod experienced bird during late progressive phase of the annual gonadal cycle. 

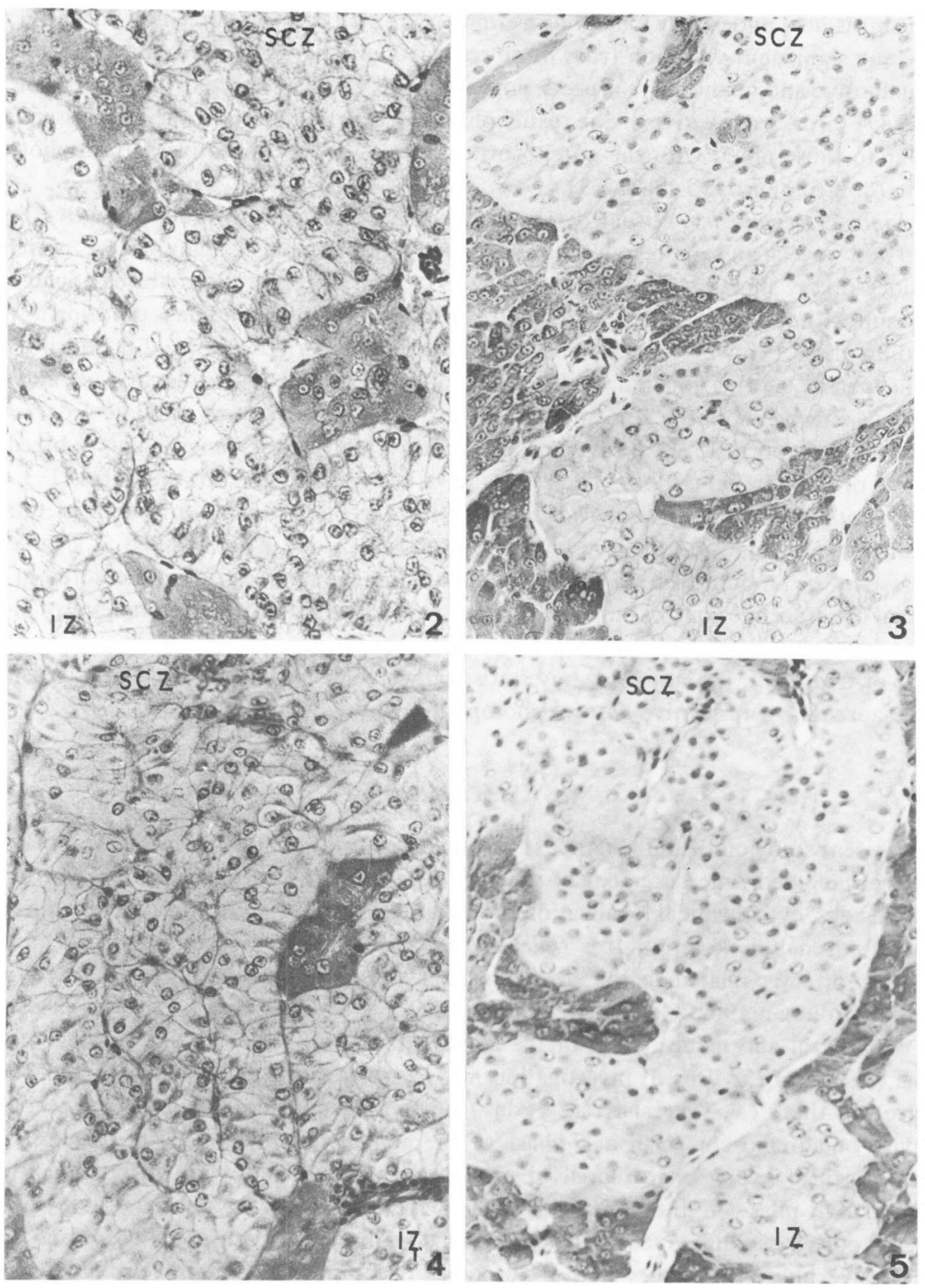
of the birds held under very long photoperiods (22 L : $2 \mathrm{D}$ ) during breeding phase did not show any significant variation from those recorded with parallel control birds (Table 3 ). In qualitative and quantitative aspects, adrenal cortex of very short daily photoperiodic ( 2 L : 22 D) birds, irrespective of the sexual phase under consideration, appeared essentially similar to those noted with the adrenocortical tissues in the respective natural photoperiodic (control) birds (Tables 1-3).

Lipid cytochemistry: Visual determination of the intensity of Sudan-reactive lipids could not reveal any appreciable change among the adrenals of any of the presently considered very short photoperiodic ( $2 \mathrm{~L}: 22 \mathrm{D}$ ) and respective control birds. Same was the result with the study of very long photoperiodic birds held for 45 days duration during breeding phase. However, treatment of very long photoperiods (22 L : $2 \mathrm{D})$ during rest of the phases of the gonadal cycle caused appreciable accumulation of Sudanophilic materials either in both the SCZ and the IZ (during early preparatory and late progressive phase) or, on only SCZ (during late preparatory, early progressive and pre-breeding phases) of the adrenal cortex. The results have been summarized in the Tables 1-3.

Quantitative study of total cholesterol: With exception to the birds treated during breeding phase, exposure of very long photoperiods (22 L : $2 \mathrm{D}$ ) resulted in significant increase in the amount of total cholesterol in adrenal, compared to that measured in the adrenal of respective control birds (see Tables 1-3). Estimation of total cholesterol in the adrenals of very short photoperiodic birds ( $2 \mathrm{~L}: 22 \mathrm{D})$, irrespective of the reproductive phase of treatment, did not show any statistically significant change from that measured in the adrenals of respective natural photoperiodic birds (Tables 1-3).

\section{Discussion}

Present study on the influences of altered photoperiods on the adrenocortical tissue in parakeet included : measurement of the cortical cord width and nuclear diameter in the cortical cells, cytochemical localization of Sudanophilic lipids and quantitative estimation of total adrenal cholesterol. It is generally agreed that secretory activity of the adrenal cortex is directly related to the sizes of nuclei and that of respective cells/tissues (cf. Fromme-Bouman 1962, Gorman \& Milne 1970, Silverin 1979) and inversely linked with the cholesterol and lipid content of the gland (cf. Harvey et al. 1986). In view of this belief, results of the present investigation may be used as the evidences in favour of the conjecture that: (a) very short $(2 \mathrm{~h} /$ day) day-length does not influence the secretory activity of adrenal cortex in any phase of the annual testicular cycle in parakeet; (b) adrenocortical responses to increased photoperiods $(22 \mathrm{~h} /$ day $)$ vary in relation to the reproductive phase of the concerned bird: (i) during breeding phase, activity of the adrenal cortex remains unaffected, (ii) during pre-breeding, late preparatory and early progressive phases, secretory activity becomes decreased only in the subcapsular zone (SDZ) of the adrenal cortex, (iii) during early preparatory and late progressive phases, adrenocorical activity becomes reduced in both the subcapsular (SCZ) and inner zones (IZ) of the gland.

Adrenocortical functions in birds are known to be related to the reproductive status 
(Silverin 1979), nutritional status (Harvey et al. 1986), plasma ionic concentrations (Manna \& Ghosh 1979), population stress (Ghosh \& Banerjee 1983), environmental stressors including adverse weather (cf. Deviche 1983), physiologic and other aspects of migration (Lorenzen \& Farner 1964) and behaviour related to territoriality (Ljunggren 1969). In the present investigation (a) population of birds during the experiments was almost the same in all the groups of birds; (b) as there was no change in the body weight in either case, nutritional status of the birds were probably unaffected (Street 1975); (c) environmental factors, other than the photoperiod, and ionic balance in the drinking water were unaltered during the tenure of treatment; (d) since the birds were maintained in captivity, probable role of behavioural changes related to the migration and territoriality does not arise. It is, therefore, not unlikely that whenever adrenocortical responses were detected in course of the present study, the responses were due to the increased photoperiods and the degree of response to long day-lengths was probably related to the sexual status of concerned parakeets.

Parallel activation of the adrenocortical tissue and the gonad under natural environmental conditions in a number of birds, like Turdus merula (Fromme-Bouman 1962), Passer domesticus (Bhattacharyya \& Ghosh 1965, Moens and Coessens 1970), Platycercus eximinus (Smith \& Brereton 1976)and Psittacula cyanocephala (Maitra 1987 b), indicated possible vis-a-vis relationship between the sexual function and the secretory activity of adrenal cortex in concerned birds. Many of the workers (Meier et al. 1971, Meier \& Dusseau 1977, Wilson \& Follett 1975, Johnson \& van Tienhoven 1981, Peczely 1985) are also in favour of the supposition that adrenocortical factor(s) is/are probably involved in the mediation of photoperiodic influences on the regulation of avian reproduction.

Influences of the altered photoperiodic regimens, as employed in the present investigation, on the testicular activity of the Blossomheaded Parakeet have been reported earlier (Maitra 1987b). The study revealed that identical duration (45 days) of long day-lengths (22 L : $2 \mathrm{D}$ ) may cause precocious maturation of testes (during late progressive phase), or involution of gonad (during breeding phase), or no change in gametogenetic and steroidogenic status of testes (during early preparatory, late preparatory and early progressive phases of the annual testicular cycle). Now, if we consider adrenocortical responses to the same experimental schedules, results showing long-photoperiod induced adrenocortical regression, in all the phases other than the breeding phase of the annual cycle, do not allow us to suggest any conclusive role of adrenal cortex in the photoperiodic regulation of testicular functions. It appears, therefore, rational to surmise that the regressive changes in adrenal cortex under very long unnatural daily photoperiods may be due to the photic stress (cf. Harvey et al. 1986), the degree of which might vary depending upon the physiological status (cf. Chaturvedi \& Thapliyal 1979) related to the sexual cycle of the parakeets and/or annual cyclicity in the daily rhythms of responsivity of adrenal to exogenous cue (Deviche 1983). Establishment of either of these possibilities, nonetheless, requires further experiments using photoperiods close to the natural cycle and determination of seasonality, if any, of daily rhythms in adrenocortical activity in the concerned bird. 


\section{Acknowledgements}

The author is very much grateful to Professor Asok Ghosh, Sir Nilratan Sircar Professor of Zoology, Histophysiology Laboratory, University of Calcutta for critical appraisal of the work. Financial assistance came from U. G. C., Govt. of India. New Delhi.

\section{References}

Ali, S. \& Ripley, S. D. 1969. Handbook of the birds of India and Pakistan. Vol. III, Oxford University Press. London.

Assenmacher, I. \& Jallageas, M. 1980. Circadian and circannual hormonal rhythms. In: Epple, A., Stetson, M. H., eds., Avian Endocrinology. Academic Press, New York, London. pp. 391-411.

Bhattacharyya, T. K. \& Ghosh, A. 1965. Seasonal histophysiologic study of the interrenal of the house sparrow. Acta Biol. Hung. 16, 69-77.

Chaturvedi, C. M. \& Thapliyal, J. P. 1979. Comparative study of adrenal cycles in three species of the Indian birds (Athene brama, Acridotheres tristis and Coturnix coturnix). Indian J. Exp. Biol. 17, 1049-1052.

Deviche, P. 1983. Interactions between adrenal function and reprodution on male birds. In: Mikami, S., Homma, K. and Wada, M., eds. Avian Endocrinology Environmental and Ecological Perspectives. Japan Sci. Soc. Press, Tokyo/Springer-Verlag, Berlin Heidelberg, New York. pp. 243-254.

Fisher, R. A. 1963. Statistical Methods for research workers. Oliver Boyd, London.

Fromme-Bouman, H. 1962. Jahresperiodische Untersuchungen an der Nebennierenrinde der Amsel (Turdus merula L.). Vogelwarte, 21: 188-198.

Ghosh, A. \& Banerjee, J. 1983. Effect of population stress on the histophysiology of avian endocrine organs. J. Yamashina Inst. Ornithol. 15: 156-166.

Gorman, M. L. \& Milne, H. 1971. Seasonal changes in the adrenal steroid tissue of the common eider, Somateria mollissima, and its relation to organic metabloism in normal and oil-polluted birds. Ibis, 113: 218-228.

Harvey, S., Scanes, C. C. \& Brown, K. I. 1986. Adrenals. In: Sturkie, P. D. ed., Avian Physiology. SpringerVerlag, New York, Berlin. pp. 479-493.

Johnson, A. L. \& van Tienhoven, A. 1981. Plasma concentration of corticosterone relative to photoperiod, ovulation and oviposition in the domestic hen. Gen. Comp. Endocrinol., 43: 10-16.

Ljunggren, L. 1969. Seasonal studies of wood pigeon populations. II Gonads, crop glands, adrenals and the hypothalamohypophyseal system. Viltrevy, 6: 41-126.

Lorenzen, L. C. \& Farner, D. S. 1964. An annual cycle in the interrenal tissue of the adrenal gland of the white-crowned sparrow, Zonotrichia lencophrys gambelli. Gen. Comp. Endocrinol., 4: 253-263.

Maitra, S. K. 1981. Hypothalamic neurosecretory system of blossomheaded parakeet and its relation with adrenocorticomedullary components under osmotic stress. Proc. Zool. Soc. Calcutta, 34: 1-28.

Maitra, S. K. 1985. Responsiveness of the adrenal cortex to testosterone propionate in relation to the sexual status of the male blossomheaded parakeet. Z. mikrosk. -anat. Forsch., Leipzig, 99: 439-446.

Maitra, S. K. 1986. Annual testicular cycle of blossomheaded parakeet, Psittacula cyanocephala (Aves, Psittacidae), under natural environmental conditions. J. interdiscipl. Cycle Res., 17: 213-223.

Maitra, S. K. 1987a. Histophysiological changes in the adrenal cortex of male blossomheaded parakeet in relation to the annual testicular and environmental cycles. J. interdiscipl. Cycle Res., 18: 249-257.

Maitra, S. K. 1987b. Influences of length of photoperiod on the testicular activity of the blossomheaded parakeet Psittacula cyanocephala. J. Yamashina Inst. Ornithol., 19: 28-44.

Maitra, S. K. \& Chakraborty, 1983. Impact of a sympatholytic drug (6-OHDA) on the osmotic stress induced changes in adrenocorticomedullary system of blossomheaded parakeet (Psittacula cyanocephala). Arch. Biol. (Bruxelles). 94: 385-398. 
Manna, C. K. \& Ghosh, A. 1979. Adrenocortical interactions following dehydration, sodium chloride, potassium chloride, cortisone acetate and desoxycorticosterone acetate treatment in the parakeet, quail and myna. $\mathrm{Zbl}$. Vet. Med. C. Anat. Histol. Embryol. 8: 106-113.

Meier, A. H. \& Dusseau, J. W. 1973. Daily entrainment of the photo-inducible phases of photostimulation of the reproductive system in the sparrows, Zonotrichia albicollis and Passer domesticus. Biol. Reprod. 8: 400-410.

Meier, A. H., Martin, D. D. \& McGregor, R. 1971. Temporal synergism of corticosterone and prolactin controlling gonadal growth in sparrows. Science, N.Y. 173: 1240-1242.

Moens, L. \& Coessens, R. 1970. Seasonal variations in the adrenal cortex cells of the house sparrow, Passer domesticus (L.), with special reference to a possible zonation. Gen. Comp. Edocrinol. 15: 95-100.

Peczely, P. 1985. Adrenocortical adaptation on birds. In: Follett, B. K., Ishii, S. \& Chandola, A., eds., The endocrine system and the environment. Japan Sci. Soc. Press, Tokyo/Springer-Verlag, Berlin, pp. 213-220.

Silverin, B. 1979. Activity of the adrenal glands in the pied flycatcher and its relation to testicular regression. Gen. Comp. Endocrinol. 38: 162-171.

Smith, M. J. \& Brereton, L. G. 1976. Annual gonadal and adrenal cycles in the eastern rosella, Platycercus eximius (Psittaciformes: Platycercidae). Aust. J. Zool. 24: 541-556.

Street, M. 1975. Seasonal changes in the diet, body weight and condition of fledged mallard (Anas platyrhynchos platyrhynchos L.) in eastern England. Trans. Ist. Intl. Congr. Union Game Biol. 12.

Wilson, F. E. \& Follett, B. K. 1975. Corticosterone-induced gonadosuppression in photostimulated tree sparrows. Life Sci. 17: 1451-1456.

Wood, J. G. 1963. Identification of and observations on epinephrine and norepinephrine containing cells in the adrenal medulla. Am. J. Anat. 112: 285-303.

Zarrow, M. X., Yochim, J. M. \& McCarthy, J. L. 1964. Experimental endocrinology: A source book of basic technique. Academic Press, New York.

\section{バライロコセイインコの副腎皮質活動に対する日照の影響}

成鳥雄バライロコセイインコを年間精巣周期の異なる段階において 45 日間にわたり毎日，長日（22L）

之短日（2L）に晒した。

日照実験を行った副腎皮質の活動は, 同時に平行して行われた自然の日照に晒した鳥と, それぞれ異 なった組織生理学的基準によって比較した。これらの基準は, 鳥の副腎のステロイド合成に関わる部分に おける分泌機能の正確な指標となるものと思われる。この研究で短日 (2L) 条件では, 年周期の如何なる段 階における副腎皮質組織の活動にも影響しないことが解った。長日 $(22 \mathrm{~L})$ に晒した鳥の副腎皮質の組織 は，繁殖期の段階では影響はなく，準備期の後期と進行期の初期及び繁殖前期の各段階では皮膜下域内に 不活発な相を示した。そして年間精单周期の準備期の初期と進行期の後期の間, 日照に晒した場合には皮 膜下域と内部域の雨方とも萎縮した。

この結果をインコにおける副腎の活動について日照の影響に関するこれまでの研究に照らして考察し た。

S. K. Maitra: Burdwan 大学動物学教室 